\title{
Görenler Sesli Betimlenmiş Bir Filmi Nasıl Anlar? Sesli Betimleme ile İlgili Bir Alımlama Çalışması Denemesi
}

\author{
How is an Audio Described Movie Perceived by Sighted Receivers? A Case Study on \\ the Reception of Audio Description
}

Araştırma/Research

\begin{abstract}
Nurhan BAŞ
Dr. Öğr. Üyesi, Hacettepe Üniversitesi, Edebiyat Fakültesi, Mütercim Tercümanlık Bölümü, Almanca Mütercim Tercümanlık Anabilim Dalı, nurhan_f_bas@hacettepe.edu.tr, ORCID ID: orcid.org/0000-00032534-4371
\end{abstract}

\section{ÖZET}

Bu çalışmanın amacı, bir sesli betimlemeli filmin, sesli betimleme kullanıcıları gibi sadece işitsel düzgüden görüntüsüz olarak izlendiğinde alımlama sürecinde karşılaşılan zorluk ve ortaya çıkan sonuçları tartışmaktır. Sesli betimleme eğitimi için yöntem arayışından doğan bu araştırmanın verileri, Mütercim Tercümanlık öğrencilerinin bir çeviri atölyesi dersi kapsamında Değirmen (Yılmaz, 1986) başlıklı Türk filminin sesli betimlemeli ve kaynak sürümüyle ilgili ürettikleri metinlerden oluşmaktadır. Çalışma, bu iki metnin karşılaştırılmasıyla açığa çıkan alımlama farklarına yoğunlaşmışır. Bu metinlerden alınan örnekler, ilgili oldukları film görselleri ve sesli betimleme örnekleriyle birlikte bir sesli betimleme kılavuzu ışı̆̆ında irdelenmiştir. Bu irdelemede sesli betimleme yer yer dillerarası çeviri yöntemleriyle ilişkilendirilmiştir. Ayrıca, betimlemede kılavuzdaki kimi kurallara kolaylıkla uyulabilirken kimilerinde güçlüklerin yaşandığı gözlemlenmiştir. Bu çalışma, bir filmin (görsel düzgüsü olmadan) sesli betimleme metniyle nasıl anlamlandırılabileceğini örnekleyerek betimleme metnini oluştururken, betimlenmiş bir filmin (görsel düzgüsü işitsel olarak iletilen bir filmin) kör ve görme engelli izleyiciler üzerinde yaratabileceği olası etkileri düşünmenin ve ifade seçiminde duyarlıık geliştirmenin ne denli önemli olduğunu vurgulamaktadır. Bu yönüyle, bu araştırma sesli betimleme eğitimine katkıda bulunmayı amaçlamaktadır. Çalışmada bazı örnekler/bulgular ise örtük cinsiyet (Braun, 2000a, 2000b) ve/veya toplumsal cinsiyet bağlamında tartışıımıştır. Çalışma, sesli betimlemenin disiplinlerarası olarak araştırı masını ve bu alanda alımlama çalışmalarının yapılmasını önererek sonuçlandırıımıştır.

*Bu makale, 3-4 Mayıs tarihlerinde Dokuz Eylül Üniversitesinde düzenlenen 32. Ulusal Dilbilim Kurultayı'nde sunulan "Gören İzleyicilere Görüntüsüz Film! Sesli Betimlemeye iliş̧kin Deneysel Bir Çalışma" başıkılı bildirinin geliştirilmiş halidir. 
Anahtar Sözcükler: sesli betimleme, Değirmen, alımlama çalışması, örtük cinsiyet, toplumsal cinsiyet

\begin{abstract}
The aim of this study is to discuss the challenges encountered by sighted viewers during the reception of audio described audiovisual products when the product is received solely through the audio channel and without the visual channel. The results obtained from this process are discussed within this framework. The study entails the search for an alternative exercise in audio description training and the data includes texts about the audio described version and source audio-visual of the Turkish movie Değirmen (Yılmaz, 1986). The texts referred to were produced by students during the translation workshop course at the Department of Translation and Interpreting. The study focuses on the differences in the reception based on a comparison. The findings are then examined on the basis of audio description guidelines which also yields results pertaining to interlingual translation. Furthermore it has been noted that whereas some guidelines seem easier to follow others tends to be more challenging. The study underlines how an audio described movie is received and underlines the importance of targeting blind and visually impaired receivers and to improving translators' sensitivity in making choices when composing the audio description text. Thus the study aims to contribute to the audio description training. Some of the examples and findings are discussed within the framework of covert gender (Braun, 2000a,2000b) and/or gender. In conclusion the study underlines the importance of conducting further especially interdisciplinary research on audio description.
\end{abstract}

Keywords: Audio description, Değirmen, reception study, covert gender, gender

\title{
1. Giriş
}

Sesli betimleme, kör ve görme engellilerin, bir ürünün görsel ögelerine/bilgilerine erişimlerini sağlayan bir çeviri türü olarak tanımlanabilir. Bu çeviri türünde herhangi bir ürünle ilgili görsel bilgiler sözcüklerle ifade edilip işitsel kanaldan aktarılmaktadır. Kör ve görme engelli kişilerin ihtiyaç duyabileceği her tür ürün için sesli betimleme üretilebilir: film, müze, sergi, tiyatro oyunu, opera, bale, görsel performanslar, afiş vs. ${ }^{1}$ Sesli betimlemenin en yoğun olarak uygulandığı alan sinema veya televizyon filmleri ve dizilerdir. Sesli betimlemeli bir film Almanca alan literatüründe Hörfilm yani işitsel film ${ }^{2}$ olarak adlandırılmaktadır. Bu terim Türkçede yaygın değildir.

Filmlerin sesli betimlemesinde, filmlerde yer alan olaylar, beden dili, yüz ifadeleri, sahne ve kostüm gibi görsel ögeler betimlenerek önemli ses ve müzik efektlerini engellemeyecek biçimde, konuşmaların bulunmadığı aralıklara kaydedilir. Aslında kör ve görme engelli bireylere, etraflarında olup bitenin görenler tarafından betimlenmesi çok eskilere dayanmaktadır (Benecke, 2004, s. 78). Ancak, profesyonel sesli betimleme uygulaması oldukça yeni sayılır. Kör ve görme engelli izleyiciler, ABD'de 80'li yılların başından beri sesli betimlemeden yararlanmaktadır ${ }^{3}$. Türkiye'de ise ilk sesli betimleme 2006 yılında, Umut Aral'ın yönettiği kısa metrajlı Çarpışma (Aral ve Atay, 2005) filmi

\footnotetext{
${ }^{1}$ Değişik sesli betimleme uygulama alanlarına ilişkin bkz. Sesli Betimleme Derneği - Hakkımızda; Sesli Betimleme Derneği - Betimleme Kumbarası.

${ }^{2}$ Bu kavram Türkiye'de yaygın olmasa da daha önce Türkçede Tanış-Polat (2009) ve Baş (2016, 21; 164) tarafından kullanılmıştır.

${ }^{3}$ Sesli betimlemenin tarihsel gelişimi hakkında ayrıntılı bilgi için bkz. Snyder (2014, 13-27); Baş (2016, 162-
} 170) 
için gerçekleştirilmiştir. Fakat, bu alanda düzenli bir üretime geçiş ancak 2011 yılının nisan ayında Kanal D’nin, izleyicileri ekrana kilitleyen Öyle Bir Geçer Zaman Ki (Günay, 2010-2013) adlı dizisi için Sesli Betimleme Derneği'ne sesli betimleme yaptırma süreciyle başlamıştır (Sesli Betimleme Derneği, Hakkımızda; Baş, 2016, s. 168). Bu yeni görsel-işitsel çeviri türü, ülkemizde bu kadar kısa bir geçmişe sahip olmasına karşın oldukça yerleşik bir yapıya kavuşmuştur. Sesli betimleme üretimi ağırlıklı olarak Sebeder'e (Sesli Betimleme Derneği) bağılı olarak yürütülmektedir ve üniversitelerden kopuk bir şekilde gelişmiştir. Sesli betimlemeye yönelik talebin giderek artacağı beklendiğinden bu alanda araştırmaya olduğu kadar eğitime de ihtiyaç duyulmaktadır. Sebeder'e bağlı olarak betimleme yazarlarının verdiği eğitimlerin dışında, sesli betimleme öğrencilere, engelsiz çeviri atölyesinde ya da çeviri atölyesi derslerinde öğretilmektedir ${ }^{4}$. Diğer bir olanak ise sesli betimlemenin, konferans vb. etkinliklerde ya da görsel-işitsel çeviri türlerinin işlendiği derslerde tanıtılması biçimindedir. Bu bağlamda Okyayuz (2017) çeviribilim öğrencilerine yönelik sesli betimlemenin tanıtımı için bir eğitim bileşeni önermektedir.

Yapmış olduğum bu çalışma sesli betimleme eğitiminde uygulanabilecek yöntem ve araç arayışından doğmuştur ve Türkiye'deki sesli betimlemenin gelişimine katkıda bulunmayı amaçlamaktadır. Bunun için bir çeviri atölyesi dersi bünyesinde Almanca Mütercim Tercümanlık öğrencileriyle bir filmin sesli betimlemeli ses kaydı ile kaynak sürümü kullanılarak alımlamaya yönelik bir çalışma düzenlenmiştir. Sesli betimleme ile ilgili kuramsal bilgiler verilirken sesli betimleme kılavuzunda yer alan bazı kurallara değinilmiştir. Değirmen (Yılmaz, 1986) filminin kısa bir tanıtımı sunulduktan sonra, gerçekleştirilmiş olan alımlama çalışmasının verileri çözümlenip örnekler sesli betimleme kılavuzundaki kurallar çerçevesinde tartışılarak, yer yer de dillerarası çeviri stratejilerine gönderme yapılarak çözüm önerileri sunulmuştur. Bazı örnekler ise örtük cinsiyet ve toplumsal cinsiyet vurgusuyla tartışılmıştır.

\section{Kuramsal Çerçeve}

Bir sesli betimleme yazarı bir film sahnesini betimlerken, bir yandan görünen her şeyi betimlemesi gerekirken diğer yandan betimlemesini kısa ve öz tutmalıdır, zira film sesli betimleme için yavaşlatılamaz ve/ya durdurulamaz. Betimlemenin boşluklara sığdırılması gerekir dolayısıyla da az sürede çok bilgi aktarmak gibi kısıtlayıcı bir zorlukla baş edilir, adeta zamanla yarış söz konusu olmaktadır. Fakat görsel düzgünün tamamen betimlenmesi de mümkün değildir, zira Cody Pfannstiehl'in de belirttiği gibi “Gözler en hızlı ağızdan bile daha hızlıdır" (Snyder, 2014, s. 33). Bunun nedeni ise görsel algılama ile dilsel algılamanın bilişsel bakımdan birbirinden farklılık göstermesidir. Bilgilerin işlenmesinde görsel algılama eşzamanlı ve holistik/bütünsel olarak gerçekleşirken, dilsel algılama ardıl ve çizgisel olarak ilerlemektedir (Nöth, 2000, s. 490).

\footnotetext{
${ }^{4}$ Sesli betimleme eğitimi Nilgin Tanış Polat tarafından Ege Üniversitesinde kurduğu Engelsiz Çeviri Atölyesi biriminde verilmiştir, çeviri atölyesi derslerinde ise tarafımdan bu konuda eğitsel uygulamalar gerçekleştirilmiştir.
} 
Zamanla sesli betimleme üretimiyle ilgili ilkeleri ortaya koyan bazı kılavuzlar ön plana çıkmıştır. Sesli betimleme kılavuzu konusunda ITC (2000), Ofcom (2017) ${ }^{5}$ ve Amerikan Körler Federasyonu'nun girişimiyle hayata geçirilen Sesli Betimleme Projesi (ADP) sayfasında (ACB, 2018) yayımlanan kılavuz örnek verilebilir ${ }^{6}$. Bu çalışmada, ABD'de her tür sesli betimlemenin yerleşmesini amaçlayan Sesli Betimleme Projesi (ADP)'nin web sayfasında sunulan sesli betimleme kılavuzundan yola çıkılmıştır. Bu kılavuz 2003 yılında Sesli Betimleme Enstitüsü'ne bağlı Sesli Betimleme Komisyonu tarafından hazırlanmıştır (ACB, 2018). Bu kılavuzun tercih edilmesinin nedeni ise, Sesli Betimleme Projesi'nin kurucusu ve koordinatörü Joel Snyder'ın 2014 yılında Sesli Betimleme Derneği'nde "Sesli Betimleme Metni Oluşturmanın Temel Unsurları ve Kuralları" başlıklı bir eğitim vermiş olmasıdır (Sesli Betimleme Derneği - Hakkımızda).

ADP sesli betimleme kılavuzunda, sesli betimlemenin tanımı verildikten sonra sesli betimleme üretimiyle ilgili konular, (1) neyin betimleneceği, (2) nasıl betimleneceği, (i) dil kullanımı, (ii) üslup ve seslendirme) ve (3) hazırlık başlıkları altında açıklanmış$\operatorname{tir}(A C B, 2018)$.

Sesli betimlemenin diğer görsel-işitsel çeviri türlerinden ayrıldığı en temel noktalardan biri, kaynak metin sözel bir metin olmadığı için nelerin betimleneceğinin betimlemeci tarafından tespit edilmesi zorunluluğudur. Kılavuzda nelerin betimleneceği konusunda, sahnede/ekranda kimin olduğu, kimin konuştuğu, mekân, mekâna giriş çıkışlar, karakterlerin fiziksel özellikleri, hareketleri, jestleri gibi örnekler verilmiştir. Kendiliğinden anlaşılmayan seslerin kaynağı da belirtilmelidir (bu konuda ayrıntılar için bkz. Benecke, 2014, s. 116-117). Kılavuza göre tanıtım yazılarının ve altyazı gibi yazılı bilgilerin okunması halinde bu bilgilerin betimlemenin bir parçası olmadığının sesli betimleme kullanıcıları tarafından ayırt edilebilmesi sağlanmalıdır (ACB, 2018). Türkiye'de üretilen sesli betimlemelerde bu ayrımın sağlanabilmesi için bazen '... yazdı' ifadesi kullanılmaktadır.

Öykü ve karakterlerin anlaşılması için gereken ögeler betimlenmelidir. Betimlenecek ögeye karar verilirken betimlemenin sığdırılacağı sessiz boşluk, yani süre dikkate alınmalıdır. Tüm kılavuzlarda konuşmaların üzerine betimleme yapılmaması konusu vurgulanmaktadır. Betimleme, önemli ses efektleri ve müzikle çakışmamalı, üst üste binmemelidir. İyi bir sesli betimleme filmi tamamlamalı, filmin işitsel düzgüsüyle bütünleşmeli ve izleyiciyi film seyrinden koparmamalıdır.

Kılavuzun dil kullanımıyla ilgili bölümünde, basit, açık, bir kere işitildiğinde anlaşılacak betimlemeler yapılmalı, [...] karakterlerin tanıtıldığı durumlar dışında olabildiğince tam cümleler kurulmalı, teknik terim kullanımından kaçınılmalı, aşağılayıcı ve ırkçı ifadeler kullanılmamalı, filminde görünür bir sansür yoksa görsele sansür uygulanmamalı, sözcük dağarı genişletilmeli, görüyoruz ifadesi kullanılmamalı şeklinde önerilere yer verilmiştir (ACB, 2018, s. 2i).

\footnotetext{
5 https://www.ofcom.org.uk/_data/assets/pdf_file/0020/97040/Access-service-code-Jan-2017.pdf

6 Türkiye'de yayımlanmış bir sesli betimleme kılavuzu bulunmasa da, Sebeder'in kendi bünyesinde hazırladığı kurallar mevcuttur (Baş 2016, 178-179).
} 
Biçem ve seslendirmeyle ilgili bölümde ise, çok gerekmedikçe konuşmaların üstüne betimleme yapılmaması, betimlemecinin kendi kişisel yorumunu katmadan betimlemesi, seslendirmede biçemin, tonun ve hızın filmin içeriği ile uyumlu olması, betimlemenin kendinden emin ve ilgili bir şekilde aktarılması/seslendirilmesi, betimlemenin filmi önemseyen bir izleyici gibi sunulması, her sessiz boşluğun doldurulmaya çalışılmaması, ses efektlerinin işitilmesinin sağlanması, mikrofonun iyi kullanılması, filmdeki espri ve korku gibi unsurların gören izleyicilerle aynı anda deneyimlenebilmesi için sahnelerin eşzamanlı olarak betimlenmesi gibi önerilerde bulunulmuştur (ACB, 2018, s. 2ii).

Kılavuzda ayrıca Türkçe betimlemelerle bağdaşmayan, şimdiki zamanı kullanarak betimleyin ve yanlışlıklara yol açabilecekse he/she zamirlerinin kullanımından imtina edin önerileri de bulunmaktadır (ACB, 2018, s. 2i).

\section{Etkinliğin Uygulanışı ve Kısıtıılıklar}

Yukarıda da belirtildiği üzere bu etkinlik sesli betimleme eğitimi için yöntem geliştirme arayışı sürecinde ortaya konmuştur ve bir çeviri atölyesi dersi kapsamında gerçekleştirilmiştir. Öğrencilere, etkinlikten önce sesli betimleme hakkında temel kuramsal bilgiler verilmiştir. Öğrenciler ayrıca internetten dizilerin betimlenmiş sürümlerini izlemeye yönlendirilmiştir. Bu olanağı sadece Kanal D ile TRT kendi dizileri için sunmaktadır. Bu deneysel etkinliğin ilk aşamasında, öğrencilere 1986 yapımı Türk filmi Değirmen (Yılmaz, 1986)'in ilk 20 dakikalık kesiti, görüntüsüz, betimlemeli ses kaydı olarak dinletilmiş ve onlardan bu film kesitini yazıya dökmeleri istenmiştir. İkinci aşamada ise aynı öğrencilere filmin yine ilk 20 dakikalık kesiti, bu defa betimlemesiz kaynak sürümden izletildikten sonra yeni görsel bilgiler ışığında filmi tekrar yazıya dökmeleri istenmiştir ${ }^{7}$. İpucu vermemek için film içeriğiyle ilgili sorular tercih edilmemiştir. Yazma aşamasından sonra, üretilen metinler incelenip ortaya çıkan bulgular sınıf ortamında tartışılmıştır.

Görenler olarak, sesli betimleme çevirmenlik mesleğinin bir alt alanı olsa da sesli betimlemeli filmleri, genellikle görüntülü izleriz. Bu etkinlikte, sesli betimlemeli bir filmi görüntü düzgüsü olmadan izleyerek hangi önemli bilgilerden yoksun kaldığımızın saptanması ve bu çeviri türünün erek kitlesiyle empati kurulması istenmiştir. Böylece, bir filmin öyküsünün ve imgelerinin zihinde daha iyi canlandırılabilmesi için hangi bilgilerin iletilmesi gerektiği ortaya çıkmaktadır. Daha önce belirtildiği üzere, sesli betimlemenin doğası gereği tüm görsel düzgünün betimlenmesi mümkün değildir. Bu yüzden engelsiz erişimi sağlamak için betimlenecek ögelerin seçimi bu çeviri türünde son derece önemlidir. Elimizde tutunabileceğimiz kaynak cümleler yoktur, kaynak filmin görsel düzgüsü vardır. Dolayısıyla görsel bilgileri sözel dile çevirirken nelerin ve hangi görsel ögelerin öncelenmesi gerektiği konusunda duyarlılık geliştirmek önemlidir.

\footnotetext{
${ }^{7}$ Öğrencilere yapılan yönlendirme: “izleyeceğiniz filmi, zihninizde canlandırdığınız biçimde ve olabildiğince ayrıntılı ve özenli yazın. Tutarlı bir metin yazmaya gayret edin. Dinlerken hatırlatma amaçlı ufak tefek not alabilirsiniz, ancak bu bir bellek çalışması değildir. Metniniz değerlendirilecek, ama not verilmeyecek."
} 
Akla gelebilecek bir soru, bu alımlama çalışması için neden Değirmen (Yılmaz, 1986) filminin seçildiğidir. Söz konusu filmin seçilmesinin en önemli nedeni öğrencilerin bilmedikleri tahmin edilen bir filmin tercih edilmesidir. Amaç, betimlemeli bir filmin sadece işitsel kanaldan deneyimlenerek zihinde oluşan canlandırmaların ifade edilmesidir. Böylece, öğrencilerin filme erişimi sesli betimleme kullanıcıları gibi işitsel düzgüyle sınırlandırılmıştır. Aksi durumda öğrenciler daha önce izledikleri görüntüleri hatırlayarak filmi zihinlerinde canlandırarak anlatacaklardır. Etkinlikte, hiçbir öğrencinin filmi daha önce izlemediği ortaya çıkmıştır. Diğer neden ise diliçi ve kültüriçi bir betimlemenin daha uygun bulunmasıdır. Dolayısıyla, dillerarası ve kültürlerarası çeviri kaynaklı sorunların yol açacağı olası bir anlama zorluğunu bertaraf etmek için öğrencilerin aşina oldukları kültürde üretilen bir film tercih edilmiştir. Film kesitinin süresini belirlerken, hem kesitin anlamlı bir öykü ortaya çıkaracak uzunlukta olması, hem de öğrencilerin sıkılmadan çalışabileceği makul bir süreyle sınırlı tutulması hedeflenmiştir.

\section{Değirmen Filmi}

Değirmen (Yılmaz, 1986), Reşat Nuri Güntekin'in aynı adlı romanından Atıf Yılmaz tarafından filme uyarlanmıştır. 1986 yapımı filmin senaryosunu Barış Pirhasan yazmıştır, müzik Arif Erkin'e aittir. Filmin konusu I. Dünya Savaşı arifesinde Osmanlı İmparatorluğu'nun küçük bir kasabası olan Sarıpınar'da geçmektedir. Sarıpınar kaymakamı Halil Hilmi Bey hafifmeşrepliğiyle bilinen Bulgar kızı Nadya nam-ı diğer Naciye Hanım'ı resmî yollardan kasabadan uzaklaştırmaya çalışmaktadır. Oturak âlemlerinde kasabadaki erkekleri baştan çıkardığı gerekçesiyle kasabalılar Naciye'yi şikâyet ederler ve kasabadan sürülmesini isterler. Ancak Naciye her defasında işveyle kendini kurtarmayı başarır. Değirmen, Osmanlı İmparatorluğu'nun çöküşünün portresini çizmektedir. İmparatorlukta yaşanan toplumsal, ekonomik, ahlaki ve dinî çöküntüler işlenmektedir.

Sarıpınar kaymakamı Halil Hilmi Bey haddini bildirmek üzere Naciye’yi makamına çağırtır. Ancak Naciye bu görüşmede rol yaparak kendine acındırır ve Halil Hilmi Bey de yumuşayıp tembihlerde bulunarak Naciye'yi gönderir. Filmin olay örgüsü, Halil Hilmi Bey'in oturduğu evin tadilatı nedeniyle karısıyla çocuklarını memlekete göndermesi ve kasaba eşrafından Ömer Bey'in bağ evi eğlencesi davetini kabul etmesiyle başlar. Kaymakam ilk kez katıldığı bu içki âleminde Naciye ile tekrar karşılaşır. Naciye kıvrak dansını icra ederken bağ evi birden sallanır. Davetliler bu sallantıyı zelzele sanıp panikle kaçışırlar. Bu kargaşada merdivenlerden yuvarlanan kaymakam yaralanır ve olmayan deprem telgrafla İstanbul'a bildirilir. Halil Hilmi Bey bir süre sonra ortada fiziki bir depremin olmadığını idrak eder. Kasabaya gelen yardım ekibi, mutasarrıf ve vali de gerçeğin farkındadır. Bunlar birer birer Ömer Bey'in bağ evine gelir. Deprem söylentisi Osmanlı İmparatorluğu'nun sınırlarını aşıp hızla tüm dünyaya yayılınca kasabadaki olmayan deprem elbirliğiyle var edilir ${ }^{8}$. 8 Değirmen filmine ilişkin ayrıntılı yorum için bkz. "Bir Devrin Sonu: Değirmen” https://filmhafizasi.com/bir-
devrin-sonu-degirmen/ (son erişim tarihi 11.07.2018) 


\section{Veri İncelemesi ve Tartışma}

\subsection{Veri İncelemesi}

Bu bölümde öğrencilerin, Değirmen (Yılmaz, 1986)'in görüntüsüz betimlemeli ve betimlemesiz sürümüyle ilgili yazdıkları metinler incelenmiştir. Ayrıntılara girmeden, görsel düzgü olmayan betimlemeli sürümle ilgili yazılan metinlerden, yani ilk metinlerden $(1)$, ufak tefek bazı hata ve eksikler dışında genel hatlarıyla, film kesitinde aktarılan öykünün anlaşıldığı ifade edilebilir. Ancak bir öğrencinin ilk metninde öykü hiç anlaşılamamaktadır. Filmin kaynak sürümüyle ilgili üretilen ikinci metinlerde $(2)$, öykü içeriği daha tutarlı ve ayrıntılı olarak ifade edilmiştir ${ }^{9}$. Çalışmada kullanılan film kesitinin sahneleri aşağıda başlıklar halinde ifade edilmiştir:

- Tarihten bilgiler (ve jenerik)

- Sarıpınar kasabası ve kasaba sakinleri (ve jenerik)

- Doktor muayene ederken

- Jandarma Hurşit'in telgrafı iletmesi

- Kaymakam Halil Hilmi Bey'in eşiyle tartışması

- Halil Hilmi Bey Jandarma Hurşit ile hükümet konağında yürüyor

- Halil Hilmi Bey'in Naciye ile makamında görüşmesi

- Hurşit'in kapı dinlemesi

- Naciye'nin ayrılışı

- Halil Hilmi Bey'in ailesini Isparta'ya uğurlaması

- Halil Hilmi Bey'in tadilatı yapan ustayla konuşması

- Kaymakamın günlük işleri

- Hocalarla karşılaşma

- Bağ evi eğlencesine davet

Yukarıda kalın olarak yazılan sahne başlıkları, aşağıda farklı açılardan tartışılmıştır. Aynı zamanda giriş çekimi olan tarihten bilgiler sahnesi ile Sarıpınar kasabası ve

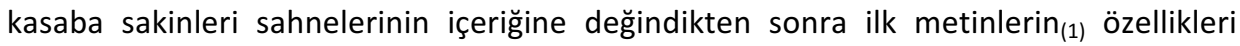
üzerinde durulmuştur.

Sesli betimlemeli sürüm, film başlığının (Değirmen) (SB örnek 1) okunmasıyla başlamaktadır. Filmin başındaki 00:00:00-00:01:43 zaman diliminde orta yaşlı bir adam kucağında oturan kız çocuğuna önündeki kitaptan resimler göstererek I. Dünya Savaşı dönemiyle ilişkili bilgiler vermekte ve değişik tarihî kişilikleri tanıtmaktadır. Kitapta birdenbire karşılarına bilinmeyen bir şahsiyet çıkar, Sarıpınar Kaymakamı Halil Hilmi Bey. Sarıpınar kasabasının 1914 yılına ilişkin bir fotoğraf vasıtasıyla o döneme geçiş yapılır.

Bundan sonra, yüksek sesle çalınan bir marş müziği eşliğinde Sarıpınar kasabası, kasaba sakinleri ve buradaki günlük yaşamdan kısa kısa sahneler gösterilmektedir, örneğin kerpiç ahşap evler, çarşıda yan yana dükkanlar, sarıklı bir esnaf, bir metni kendi

\footnotetext{
${ }^{9}$ Aynı filmin, farklı sürümlerle de olsa, ikinci kez izlenmesinin de ikinci metinlerin niteliğini etkilemiş olması muhtemel olmakla birlikte kaçınılmazdır.
} 
yazmış gibi okuyan bir adam, kalaycı dükkânı, kültür fizik hareketleri yapan adama bakıp eğlenen çocuklar, doktor, ayakkabı tamircisi, eczacı, çay içen kasabalılar vs. Arada da konuşmalara yer verilmektedir. Aynı zamanda jenerik akmaktadır. Filmlerin giriş planı yoğun bilgi içerdiğinden bu kısımların betimlemesi ayrı bir itina gerektirmektedir. Bu kısımda hem önemli bilgiler verilerek kurgunun temelleri atılmakta, hem de tanıtım yazısı aktarılmaktadır. ADP $(A C B, 2018)$ kılavuzu, jenerikteki yazıların zaman elverdiği ölçüde okunmasını önermektedir.

\subsection{Metin üretimini etkileyen unsurlar}

İncelemede metinlerin ${ }_{(1)}$ öykü içeriğini aktarma bakımından önemli farklılıklar barındırdığı tespit edilmiştir. Kişisel anlama ve yazma yetenekleri göz ardı edildiğinde bu farklılıklar fazla ayrıntıya girmeden iki nedene bağlanabilir. Farklılıklar, betimlemeli sürümün ses aktarımı tekniğiyle ve metin üretme stratejisinde uygulanan tutumla ilişkilendirilmektedir. Sarıpınar kasabası ve kasaba sakinleri sekansına eşlik eden film müziği yüksek sesle aktarılmaktadır. Öğrencilerin bir kısmı buradaki betimlemelere odaklanmakta zorlanmışlardır ve bunu metinlerde $(1)$ de açıkça ifade etmişlerdir. Bu durum sadece teknik bir konu gibi görünse de, sesli betimleme kullanıcılarının zaman zaman dillendirdikleri bir sorun olarak karşımıza çıkmaktadır. Sesli betimlemenin işitilebilmesi için müzik ve ses efektlerinin biraz kısılması söz konusu olabilmektedir. Aksi takdirde çok nitelikli bir betimleme teknolojik bir sorundan dolayı başarısızlığa uğrayacaktır.

Öğrenciler ${ }^{10}$ metinleri $_{(1)}$ kaleme alırken farklı stratejiler uygulamıştır. Kimi metin$\operatorname{ler}_{(1)}$ oldukça bağdaşık ve anlaşıır bir biçimde ifade edilmiştir. Ancak, bu örneklerde bazı sahnelerin yazıya dökülmediği görülmektedir. Tam olarak anlaşılamayan, belirsiz kalan ve öyküyle bütünleştirilemeyen kısımlar metne(1) dâhil edilmemiştir. Örneğin kaymakamın bağ evine davet edilmesi bazı metinlerde $(1)$ ya hiç belirtilmemiştir (3- $m_{(1)}$, 11- (1) ya da "Bağ evine geçiliyor." (5- $\mathrm{m}_{(1)}$ ) gibi genel bilgi verilmiştir. Jandarma Hurşit'in kapı dinleme sahnesi de [3- $\mathrm{m}_{(1)}, 1-\mathrm{m}_{(1)}, 10-\mathrm{m}_{(1)}, 2-\mathrm{m}_{(1)}$ ] hiç aktarılamayan ya da kavranmadığı için yanlış bir biçimde bağdaştırılan sahnelerden biridir. Ustayla konuşma sahnesi de metinlere ${ }_{(1)}$ yansıtılmayan ve açıkça ifade edilmeyen [4- $\mathrm{m}_{(1)}$ ] bilgilerdendir. Bu bağlamda elbette, algılanan tüm bilgilerin yazıya döküldüğü ve herhangi bir bilgi yazıya dökülmediyse de anlaşılmamış olduğu iddia edilmemektedir. Diğer taraftan, örneğin tarihten bilgiler sahnesini bir öğrenci önce metnine $(1)_{(1)}$ yansıtmazken sonraki metninde [1- $\mathrm{m}_{(2)}$ ] anlatmıştır. Bazı sahnelerin, öykünün aktarımı için gereksiz görüldükleri için dillendirilmediği düşünülebilir. Örneğin hocalarla karşılaşma sahnesine metinlerin çoğunda yer verilmemiştir.

Olabildiğince ayrıntılı ifade edip, ancak aynı zamanda, anlamada yaşanan belirsizlikleri gizleme gayreti gütmeden yazılmaya çalışılan metinlerde ${ }_{(1)}$, sahnelerin zihinlerde nasıl canlandırıldığına ilişkin daha somut veriler ortaya çıkmıştır. Sesli betimlemeli filmi dinlerken aklından geçenleri an be an adeta rapor şeklinde not alan, tereddütlerini de ifade eden öğrencilerin metinlerindeki ${ }_{(1)}$ veriler, sesli betimleme metnini yazarken hangi unsurlara dikkat edilmesi gerektiği konusunda daha fazla dönüt sağlamaktadır.

\footnotetext{
${ }^{10}$ Metinlerden örnekler verilirken her bir öğrenci 1-12 arasında bir sayıyla ifade edilmiştir.
} 
Bu zihinsel canlandırmaların / temsillerin metinlere ${ }_{(1)}$ önce nasıl yansıtıldığını ve filmi görüntülü olarak izledikten sonra yazıya dökülen metinlerde ${ }_{(2)}$ söz konusu kısımların nasıl ifade edildiğini göstermek için aşağıda dikkat çeken birkaç örnek tartışılmıştır.

\subsection{Tartışma Örneği: Çocuk}

$\mathrm{Bu}$ örnekte filmin giriş kısmından tarihten bilgiler sahnesi incelenmiştir. Bu sahnenin başından ve sonundan olmak üzere iki film karesine yer verilmiş ve ilgili sesli betimleme (SB) örnekleri sunulmuştur:

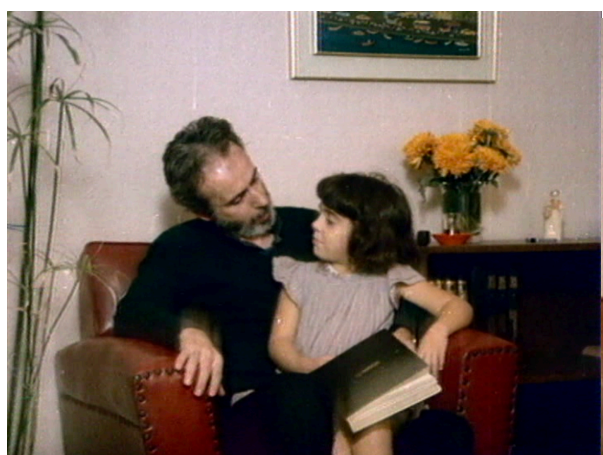

Ekran görüntüsü: 1

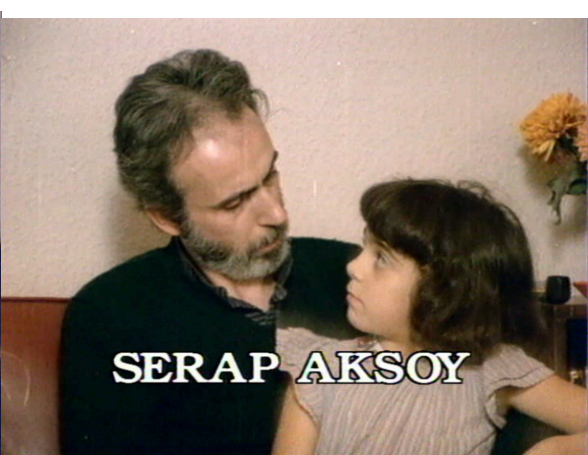

Ekran görüntüsü: 2

SB 1: "Değirmen" (00:00:00)

SB 2: "Kucağındaki çocuğa kitaptan gösteriyor. Şaşkınca bakıştılar." (00:01:29 00:01:32)

Sesli betimleme ancak görsel-işitsel ürünün işitsel düzgüsüyle ilişkilendirilerek anlamlandırılabildiği için sesli betimleme örnekleriyle birlikte diyalog dökümüyle ses efektleri de aktarılmıştır. Görsel düzgüye ilişkin sadece jeneriğe yer verilmiştir, kitaptan gösterilen resimlerin konusu konuşmada geçtiğinden bunların ayrıca betimlenmesine gerek duyulmamıştır. İşitsel düzgünün dökümü öğrenci tercihlerine ışık tutması bakımından da önemlidir. Dökümde sesli betimleme tırnak imleri içinde ve eğik olarak, diyaloglar da tırnak imi içinde ancak düz bir şekilde yazılmıştır. Konuşmalara eşlik eden diğer sesler ve ses efektleri çifter küçüktür ve büyüktür imleri ( $<<>>)$ içinde açıklanmıştır ve bunlar sesli betimlemede yer almamaktadır:

\begin{tabular}{|c|c|}
\hline Jenerik & $\begin{array}{l}\text { İşitsel düzgü } \\
\text { Diyalog dökümü ve ses efektleri (00:00:00-00:01:43) }\end{array}$ \\
\hline $\begin{array}{l}\text { Bir ATIF YILMAZ } \\
\text { Filmi }\end{array}$ & $\begin{array}{l}\text { SB örnek 1: “Değirmen” } \\
\text { Adam: } \\
\text { "Kaçıncı yüzyıldayız biz şimdi?" } \\
\text { Çocuk: } \\
\text { "Yirminci." } \\
\text { Adam: } \\
\text { "Aferin. Bak şimdi. Bu, Alman İmparatoru Kayzer Wilhelm." <<Sayfa } \\
\text { çevirme sesi>> "Bunlar İngiliz askerleri, gaz maskeleriyle." <<Sayfa }\end{array}$ \\
\hline
\end{tabular}




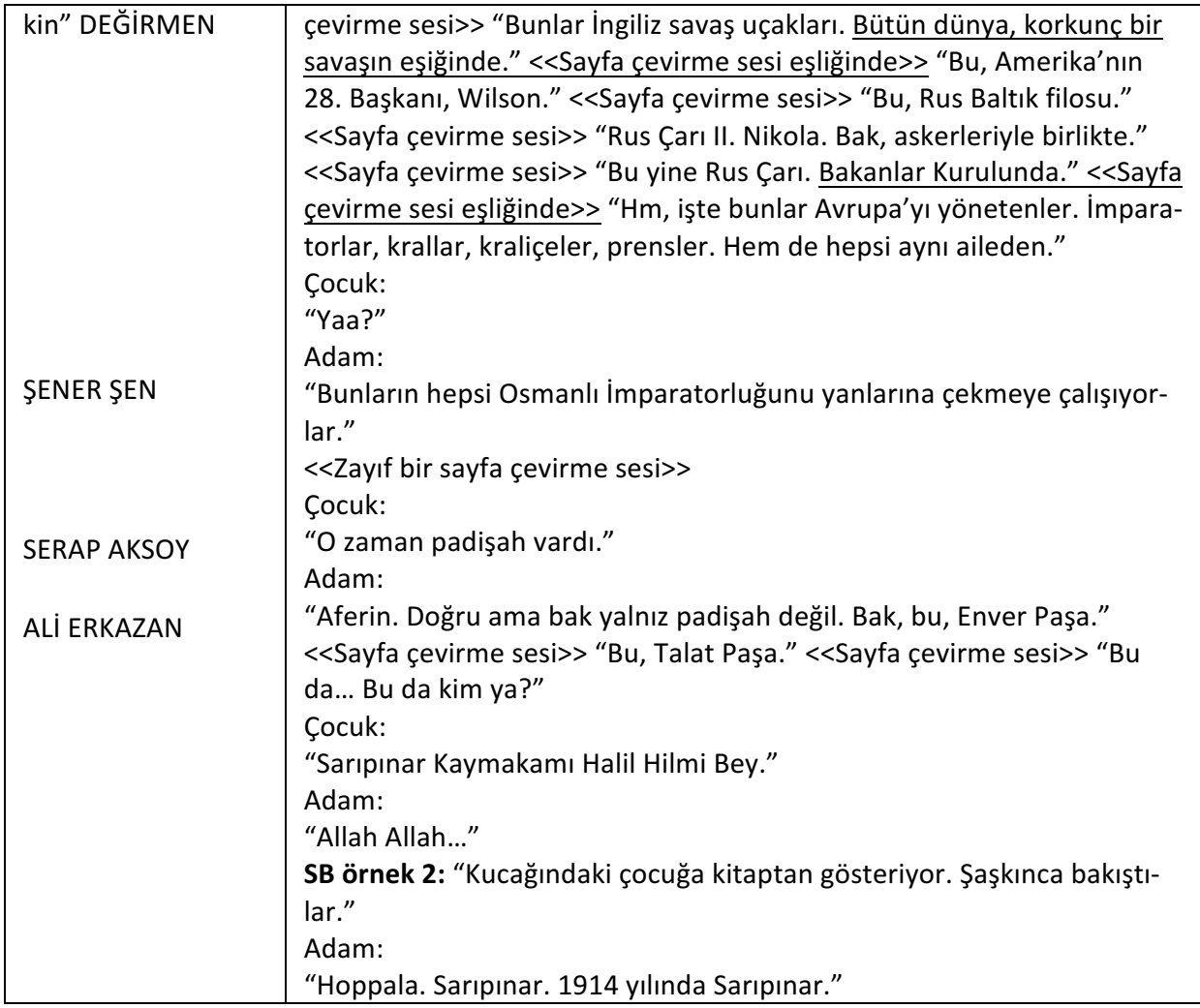

İşitsel düzgünün dökümünde, SB örnek 2'nin oldukça geç, tarihî bilgilerden sonra verildiği görülmektedir. Bu zaman kısıtından kaynaklanmaktadır. Betimlenecek olan görsel düzgü olsa da, betimlemenin zamanlamasını işitsel düzgü yönlendirmektedir. Betimleme yazarı, konuşmaların yoğun olduğu kısımlarda konuşmaların üzerini betimlememe altın kuralını çiğnemeyecekse betimlemeyi daha geç vermek durumda kalacaktır. İlkesel olarak, görsel-işitsel çeviride eşzamanlılık ölçütüne uymak nitelikli bir erek metnin üretilmesi için çok önemlidir. Ancak, sesli betimlemede, betimlemeli filmin özünü etkilemeyecek ölçüdeki kaymalar sorun yaratmamaktadır. Bir görsel, ekranda yer aldığı zamandan önce ya da sonra betimlenebilir. Hatta ses efektlerinin betimlemesi genellikle (olabiliyorsa) sesten hemen sonra yapılır. Zaten ses efektiyle betimleme üst üste gelmemesi gerekmektedir. ${ }^{11}$ Ancak, bir görselin betimlemesinin yerini belirlerken bu kaymaların alımlamayı nasıl etkileyebileceği de düşünülmelidir. Sınıf ortamında tarihten bilgiler sahnesi tartışılırken bazı öğrenciler, betimlemede kitap kavramı geçene kadar bu sahneyi daha farklı hayal ettiklerini belirtmişlerdir. Bazıları bu kesitteki sayfa çevirme ses efektini hiç hatırlayamazken, örneğin bir kişi de bu sesi eski tipte bir dia

\footnotetext{
${ }^{11}$ Okyayuz $(2017$, s. 573) da bu bağlamda, sesli betimlemede eşlemenin bire bir oturmamasının hiçbir sakınca yaratmadığııı, hatta "çoğu görsel-işitsel çevirmendeki mesleki 'deformasyon' haline gelmiş eşlemeyi bire bir oturma çabasının sesli betimleme bağlamında kimi zaman gereksiz ve yersiz olacağı” düşüncesini ifade etmiştir.
} 
projeksiyon cihazının çıkardığı sese benzettiğini ifade etmiştir. Bu ses efektini hiç algılamayıp resimleri büyük tek parça bir pano/afiş/sayfa olarak düşünenler de olmuştur. SB örnek 2 daha erken verilebilseydi ses efekti doğru bir şekilde anlamlandırılabilecekti. Bunun için ilk ses efektinden sonra gelen kısa konuşma parçalarından birinin üzerine betimleme yapılması gerekirdi. Bu da altın kuralı çiğnemek anlamına gelmektedir. Bunun için dillerarası çeviride olduğu gibi göstergelerarası çeviri olan betimlemede nelerin aktarılmasının öncelikli olduğuna karar verilmelidir.

Aşağıda tarihten bilgiler sahnesinin öğrenci anlatımlarına nasıl yansıdığı gösterilmiştir. Daha önce belirtildiği gibi giriş çekiminin bu sahnesinden bir metinde ${ }_{(1)}$ hiç bahsedilmemektedir. Aşağıda, bu sahneye ilişkin öğrenci metinlerinden ${ }_{(1,2)}$ örnekler verilmiştir. Örneklerdeki anlatım, cümleler elverdiğince ekran görüntüsü 1 ve 2'nin içeriyle sınırlı tutulup aynı kişiye ait örnekler yan yana aktarılmıştır:

Öğrenci anlatımlarından örnekler

\begin{tabular}{l}
\hline Betimlemeli sürüme ilişkin anlatımlar $\left[\mathrm{m}_{(1)}\right]$ \\
Film, birinci dünya savaşını çocuğuna anlatan \\
bir babanın konuşmasıyla başlıyor. $\left[2-\mathrm{m}_{(1)}\right]$ \\
Filmin başlangıcında 20. yüzyıldan bir adam bir
\end{tabular}

çocuğa tarih kitabından I. Dünya savaşı hakkında resimli bilgiler vermektedir. (...) İkisi de çok şaşırır (...). [4- $\left.\mathrm{m}_{(1)}\right]$

Bir baba ve oğul yan yana oturmuşlar. Baba, oğluna önünden (...) resimlerini gösteriyor. [10- $\left.\mathrm{m}_{(1)}\right]$

Filmin başında bir baba oğluna (ya da dede torun) Büyük Savaşın önemli figürlerinin fotoğraflarını göstermekte... [9- $\left.\mathrm{m}_{(1)}\right]$

--- $\left[1 \mathrm{~m}_{(1)}\right]$
Kaynak sürüme ilişkin anlatımlar $\left[\mathrm{m}_{(2)}\right]$

Filmin başında bir baba ve kızı tekli bir koltukta oturup tarih kitabına bakmaktadır. (...) sonra hiç tanımadıkları bir fotoğrafa şaşkınlıkla bakarlar. [2- $\left.\mathrm{m}_{(2)}\right]$

20. yüzyılda bir kız çocuğunu kucağına oturtmuş bir adam kıza tarihte yaşamış önemli kişilerin resimlerini gösterir (...) Adam bu duruma çok şaşırırken kız gayet normal karşılar. [4- $\left.\mathrm{m}_{(2)}\right]$

Bir kız çocuğu babasının kucağında oturuyor. Babanın elinde bir kitap. [10- $\left.\mathrm{m}_{(2)}\right]$

Bir baba çocuğuna (ya da dede - torun) Büyük Harp'in önemli figürlerini gösterip (...)[9- $\left.\mathrm{m}_{(2)}\right]$

Filmin başında bir baba ve kızı tarih kitabındaki fotoğraflara bakıyorlar (...) [1- $\left.\mathrm{m}_{(2)}\right]$

Adamla kız arasında geçen konuşmayı dinleyen öğrencilerden hiçbiri betimlemeli sürümle ilgili anlatımlarında, örnek 2'de bahsedilen çocuğu kız çocuğu olarak betimlememiştir. On iki öğrenciden çoğu sesli betimlemedeki çocuk sözcüğünü kendi anlatımlarında yine çocuk (ya da torun) olarak ifade etmiştir. Bir öğrenci bu sahneye hiç değinmezken üç öğrenci ise çocuk sözcüğü yerine oğul demeyi tercih etmiştir. Bu durumda öğrencilerin bir kısmı çocuk kavramını zihinlerinde eril olarak canlandırmıştır. Yazma işlemlerinden sonra sonuçların tartışıldığı sınıf ortamında öğrencilerin yarısının çocuk kavramını erkek çocuk olarak düşündükleri ortaya çıkmıştır. Buna karşın birkaç öğrenci de, çocuk kavramını bir cinsiyetle bağdaştırmadıklarını belirtip hatta çocuk eşittir erkek çocuk ilişkisini tuhaf karşılamıştır. Sonuç olarak sesli betimleme, öğrencilerin \%50'sinde görsel düzgüde olmayan cinsiyeti çağrıştırmıştır. Dolayısıyla bu çağrışımın kaynağı irdelenmelidir. Söz konusu çağrışımın temelinde ne yattığını çözümlemek için çocuk sözcüğünün sözlükte nasıl açıklandığına bakmakta fayda vardır. 
Misalli Büyük Türkçe Sözlük'te çocuk madde başı altında şu bilgilere yer verilmektedir:

ÇOCUK i. (Eski dönemlerden beri kullanılır (...)) 1. "Büyüyünceye kadar olan devresinde insana verilen isim, insan yavrusu: "Çocuk ve Ana sağlığı." (...) 2. Bir kimsenin dünyaya gelmesine sebep olduğu oğul veya kız, velet: (...). 3. teşmil. (Erkekler için) Adam, kişi: "Çok iyi çocuktur." (...) 4. (Isim tamlamasının ikinci öğesi olarak) Bir yer veya memleket halkından olan kimse: (...) 5. mec. Düşünce ve davranışları yaşına göre yeterince olgunlaşmamış, yaşı büyüdüğü halde duygu ve fikirleri çocukluk seviyesinde kalmış kimse: (...) (Ayverdi, 2011, s. 602)

Bebek sözcüğünde olduğu gibi, çocuk sözcüğünün insan yavrusu anlamında (1. ve 2.) düşünüldüğünde bu kavramın cinsiyete işaret etmediği ya da etmemesi gerektiği akla gelebilir. Ancak kullanımda durum böyle değildir. 3. anlamında ise çocuk, "yakışıklı çocuk" örneğinde de olduğu gibi "genç erkek" anlamında kullanılmaktadır.

Türkçede adları dişil, eril vb. kategorilerine ayıran bir dilbilgisel cinsiyet sistemi bulunmamaktadır $^{12}$. Bu nedenle biyolojik cinsiyet semantik olarak sözlüksel düzlemde ortaya çıkar; örneğin anne ve baba sözcüklerinde olduğu gibi. Insanları ifade eden biçimsel olarak yansız adlar anlam bakımından cinsiyet yansızlığını sağlamayabilmektedir. Zira her iki cinsiyeti ifade eden yansız adların da belli bağlamlarda eril cinsiyeti ifade edebildiği dil kullanımından bilinmektedir. Örneğin, sözlüksel düzlemde belli bir cinsiyeti ifade etmeyen genç sözcüğü (ad), tekil olarak kullanıldığında genç insanı değil, eril cinsiyeti karşılayıp erkeği ifade etmektedir. Böylece bir ad hem her iki cinsiyeti birlikte, yani cinsiyeti işaretlemeden, hem de örtük olarak sadece eril cinsiyeti işaretleyerek kullanılabilmektedir. Ayrıca, cinsiyetle ilgili dilsel bir belirleme olmadığı halde birçok meslek, uygulayıcılarına göre ağırıklı olarak belli bir cinsiyeti çağrıştırır. Braun'a göre, örneğin çocuk bakıcısı dişil, polis ise eril bir kişiyi çağrıştırmaktadır. Bu olguya örtük cinsiyet (covert gender ${ }^{13}$ ) denmektedir (2000a, s. 4) ${ }^{14}$. Türkiye'de hâlâ kadın istihdamı düşük bir seviyede bulunduğuna göre, iş hayatında da daha fazla erkek çalışanla karşılaşıldığından çağrışım eğilimi eril olacaktır. Ancak, bu 'ya hep ya hiç' tarzında bir ikili sistem değildir.

Bunlara ek olarak, insanlarla ilgili adlandırmalarda cinsiyetin belirtilmesi konusunda genel bir eğilim ortaya çıkmaktadır: Dişil kişileri ifade ederken cinsiyeti açıkça belirtme eğilimi daha yüksektir. Böylece dişil niteleyiciye sahip olmayan kişiler eril işaretlidir. Başka bir deyişle, bu durumda eril işaretleme baskınlığı ortaya çıkmaktadır.

\footnotetext{
${ }^{12}$ Birçok Hint-Avrupa dilinde, adları dişil ve eril (ya da dişil, eril ve yansız/nötr) olarak sınıflandıran dilbilgisel cinsiyet sistemi vardır. Örneğin Almancada dilbilgisel cinsiyete göre, sandalye (der Stuhl) eril, pantolon (die Hose) dişil ve kitap (das Buch) yansızdır.

${ }^{13}$ Ingilizcede kullanılan bu kavramı Baron (1986, s. 176 aktaran Braun, 2000b, s. 4) Eduard Maetzner'in 1874 tarihli İngilizce dilbilgisi kaynağına dayandırmaktadır.

${ }^{14}$ Türkçede bu konuda iki ayrı belirtim kullanılmaktadır, gizli cinsiyet (Kerimoğlu / Doğan, 2015) ile örtük cinsiyet (Peçenek / Gökmen, 2018, s. 34). Yazarlar ayrıca gizli/örtük cinsiyet ile çağrışımsal cinsiyet ayrımı yapmaktadırlar. Bu çalışmada böyle bir ayrıma gidilmemiştir.
} 
Böylece dişil cinsiyeti belirtmek için kız çocuk denildiği için diğer bağlamlarda çocuk sözcüğü de eril olarak işaretlenmektedir (krş. Braun, 2000a, s. 17). ${ }^{15}$ Bu durum, tek bir çocuğun kastedilmediği, çocuk eğitimi, çocuk edebiyatı gibi örnekler için geçerli değildir. Bunların dışında çocuk dendiğinde hangi cinsiyetin kastedildiğini zihnimizdeki kalıplara (ya da zihinsel temsillere) dayalı olarak çıkarım yoluyla saptayabiliriz. Bu durumda "Çocuklar sokakta futbol oynuyor." ile "Çocuklar bahçede bebekleriyle oynuyor." cümleleri, bağlamlarına göre farklı zihinsel şemalar etkinleştirileceğinden ayrı çağrışımlara neden olabilecektir. Sesli betimleme metninde çocuk sözcüğünün nasıl kullanıldığını göstermek için çocuk ile ilgili metninde geçen tüm örneklemler aşağıda sesli betimlemeli filmdeki zaman koduyla birlikte sunulmuştur:

SB 3: "Tepede bir araya toplanmış, avluda spor yapan burma bıyıklı adamı izleyerek eğlenen erkek çocuklar." [00:02:58] [DVD görüntüsü 00:02:18-00:02:24]

SB 4: "Karısı, kızları da almış, oğlan çocuklar peşlerinden koşturuyorlar." [00:14:39] [Araştırmacının notu: Bir kız çocuğu da bulunmaktadır.]

SB 5: "Çocuklar, yine tepeden mühendisin avlusunu dikizleyerek eğleniyorlar. Halil Hilmi'yle mühendis spor yapıyorlar." [01:20:45]

SB 6: "Harabe evin içinde yer yatağında yatan yaşlı bir kadın. Sokakta yatan yaşlı bir adamla çocuk." [01:23:18] [Araştırmacının notu: Kısa saçlı bir oğlan çocuğu]

SB 7: “Ortaya ateş yakılmış, yetişkinler halay çekiyor, çocuklar aralarında oynuyorlar." [01:31:19] [Araştırmacının notu: oğlan çocukları]

Yukarıda bahsedilen eğilimin tersine, sunulan örnekler sesli betimleme metninde iki kez eril cinsiyetin belirtilmiş olduğunu göstermektir: eğlenen erkek çocuklar, oğlan çocuklar. Bu durum yukarıda açıklanan cinsiyet işaretleme eğilimine pek uymamaktadır. SB örnek 4'te arkadan gelen bir kız çocuğu fark edilmemiştir. SB örnek 5'te ise SB örnek 3'teki eğlenen erkek çocuklar kastedildiğinden cinsiyetin belirtilmesine gerek duyulmamış olabilir. SB 6 ile 7'de de erkek çocukları söz konusudur. Yukarıdaki betimleme örneklerine bakıldığında, eril cinsiyetin bazen belirtilip bazen de belirtilmemesinden, incelenen sesli betimleme metninde yukarıda bahsedilen cinsiyet belirtme konusunda tutarlılık sergilenmediği anlaşılmaktadır. Filmi sesli betimlemeyle kavramaya çalışanların zihninde ise, en azından yarısında, görseldekinden farklı imgeler canlanmıştır. Yukarıda irdelenen tartışma örneği sonuç bölümünde toplumsal cinsiyet açısından ele alınmıştır.

\subsection{Tartışma Örneği: Stetoskopsuz Doktor}

Filmin giriş çekiminde jenerikle birlikte bir doktor hastasını muayene ederken gösterilmektedir (ekran görüntüsü 3 ve 4: 00:02:27):

\footnotetext{
${ }^{15}$ Türkçede cinsiyet olgusunu etraflıca araştıran Braun (2000b, s. 78, 81) çocuk sözcüğünde de kısmen, oğul sözcüğünün geçirmiş olduğu türden bir anlam daralması belirtilerinin görüldüğünü ifade etmektedir. Eski Türkçe döneminde cinsiyet bildirmeyen oğul sözcüğü zamanla erkek çocuğu anlamında kullanılır olmuştur.
} 


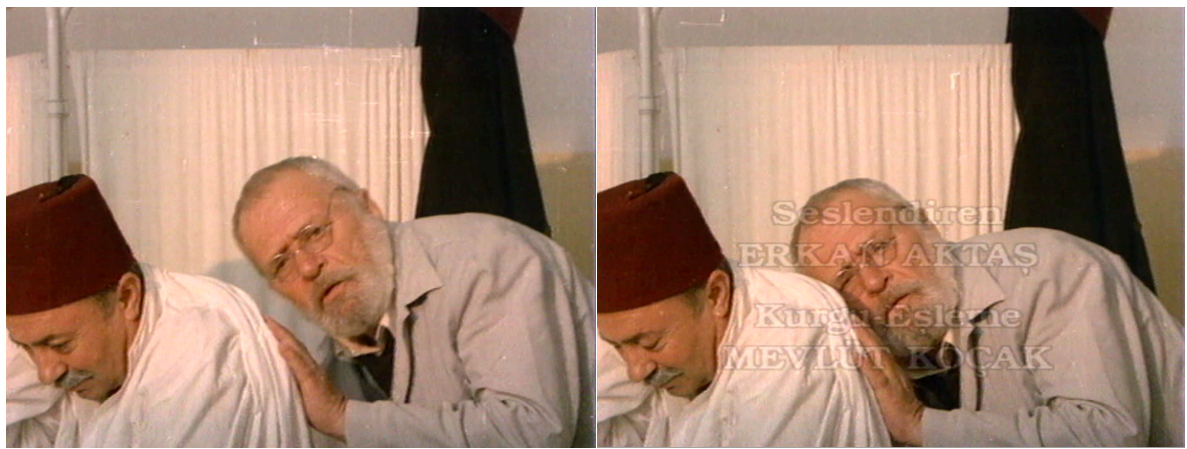

Ekran görüntüsü: 3 ve 4

SB 8: "Stetoskop yerine kulağıyla hastasının ciğerlerini dinleyen yaşlı bir doktor. Muayeneyi bitirip masasına geçti, reçete yazıyor." [00:02:26-00:02:36]

Görselde yaşlı hekim çıplak kulağını hastanın sırtına dayamış akciğerlerini dinleyerek muayene ediyor. Hekim muayenesini stetoskopsuz yapıyor. Görüntünün hiçbir yerinde stetoskop bulunmamaktadır. Stetoskobu betimleme yazarı kendi dünya bilgisinden tamamlamıştır. Kılavuzlarda, sadece görüntüde bulunan bilgilerin betimlenmesi gerektiği ifade edilmektedir. Gören izleyicilere sunulmayan bir bilgi kör ve görme engelli izleyicilere de verilmemelidir (Guidelines on the Provision of Television Access Services, 3.8.). Zira sesli betimlemenin amacı görmeyen izleyicilere bir avantaj sağlamak değildir. Stetoskobun yokluğunu çıkarım yaparak izleyici kendisi tespit etmelidir. SB örnek 8'deki betimleme yöntemi dillerarası çevirideki açımlama çeviri tekniğini akla getirmektedir.

Fakat tüm bilgilerin açımlama çeviri tekniğiyle betimlenmesi söz konusu değildir. Örneğin, muayene sahnesindeki yaşlı doktor doğrudan belirtilmiştir, doktorun mesleğini erek izleyicinin çıkarım yoluyla bulmasına çalışılmamıştır. Elbette sözcüğü sözcüğüne çeviri yaparcasına görseldeki bilgiler teker teker betimlenebilir. Ancak, böyle bir uygulamaya ne gerek var ne de zaman. Bu tarz bir tutum, sahneyi bir bütün olarak gözden çıkarıp görseldeki "nesneleri” ön plana çıkarmak anlamına gelir. Bu tür uygulamalar, betimlemeli filmin anlaşılmasını zorlaştırabilir. Ayrıca, kaynak izleyici için bu sahnedeki olayın doktor muayenesi olduğu aşikârdır. Dillerarası çeviri kavramlarını kullanarak ifade edilecek olursa, sesli betimlemede sadakat ya da bağlılık tek tek görsel ögelere yönelik değil, film öyküsünün bütününe yönelik olmalıdır.

Resim 3'teki sahneyi bazı öğrenciler müziğin yüksek sesle verilmesinden dolayı takip edememişlerdir. Bazıları ise birkaç sahneyi özetleyerek ifade etmişlerdir. Aşağıda bu sahneye değinen öğrencilerin metinlerinden $(1,2)$ örnekler sunulmuştur: 
Öğrenci anlatımlarından örnekler

\begin{tabular}{l|l}
\hline Betimlemeli sürüme ilişkin anlatımlar $\left[\mathrm{m}_{(1)}\right]$ & Kaynak sürüme ilişkin anlatımlar $\left[\mathrm{m}_{(2)}\right]$ \\
\hline $\begin{array}{l}\text { (...) stet[e]skopu }{ }^{16} \text { olmadan kulağıyla hastayı } \\
\text { dinleyen bir doktor }(\ldots)\left[7-\mathrm{m}_{(1)}\right]\end{array}$ & $\begin{array}{l}\text {...köyün halkının günlük hayatı gösteriliyor; } \\
\left.\text { eczacı, doktor, okuldaki çocuklar [7- } \mathrm{m}_{(2)}\right]\end{array}$ \\
Jenerik kısmında doktor sahnesi var [8- $\left.\mathrm{m}_{(1)}\right]$ & $\begin{array}{l}\text { Jenerikle beraber hastasını stetoskopla tedavi } \\
\left.\text { eden bir doktor (...) [7- } \mathrm{m}_{(2)}\right]\end{array}$ \\
---- $\left[9-\mathrm{m}_{(1)}\right]$ & $\begin{array}{l}\text { Bu zavallı kasabanın detayları üstünkörü anla- } \\
\text { tılıyor (stetoskopsuz doktor, dökülen binalar } \\
\left.\text { vb.) ... [9- } \mathrm{m}_{(2)}\right]\end{array}$
\end{tabular}

[8- $m_{(2)}$ örneğinde dikkat çeken husus bu anlatımın sahnenin içeriyle örtüşmemesidir. Muhtemelen stetoskop terimi anlaşılmamıştır. [9- $m_{(2)}$ ] örneğinde ise bu sahnenin filmdeki işlevine işaret edilmiştir: stetoskopsuz doktor, dökülen binalar vs. kasabanın zavalıı̆̆ının daha doğrusu Osmanlı İmparatorluğu'nun ekonomik durumunun göstergesidir. Metinlerde(2) aynı sahnenin, farklı alımlama nedeniyle değişik yönlerine ağırlık verildiği görülmektedir.

\subsection{Tartışma Örnekleri: Halil Hilmi Bey'in Naciye ile makamında görüşmesi}

Halil Hilmi Bey'in Naciye ile makamında görüşmesi sekansından iki örnek tartışılmıştır. İlkinde görüşme sırasında Hurşit'in kapıyı dinlemesini ikincisinde de Naciye'nin kaymakamın odasından ayrılışı ele alınmıştır.

Kaymakam Halil Hilmi Bey kendisine gönderilen telgraftan sonra Naciye'yi uyarmak için makamına çağırtmıştır. Jandarma Hurşit kırmızı çarşaf içinde Naciye'yi bu görüşme için hükümet konağına getirir. Halil Hilmi Bey Naciye'yle hemen görüşmez ve bekletir. Bu esnada Jandarma Hurşit Naciye'yi kaymakamın selefi gibi yumuşak yüzlü olmadığı konusunda uyarırken kaymakam da biraz heyecanlanıp aynanın karşına geçerek kendine çeki düzen verir. Jandarma Hurşit Naciye'yi kaymakamın odasına almadan önce tekrar uyarır. Aşağıda önce bu sekansta geçen sesli betimleme örnekleri sonra da işitsel düzgünün dökümüne yer verilmiştir.

Sesli betimleme örnekleri [00:09:27 - 00:11:31]:

SB 9: "Hurşit kapıyı itti... Naciye içeri girince geri çekti."

SB 10: "Naciye, çarşafın ucunu yüzüne kapamış, güya pek bi' mahcup çekingen."

SB 11: "Ağlamaklı oldu, bakışlarını yerden kaldırmıyor."

SB 12: "Yüzünü açtı."

SB 13: "Sendeleyip masaya tutundu."

SB 14: "Sandalyeye oturma ayağına yalandan kollarına yığılıverdi. Halil Hilmi sandalyeye oturttu. Arkasından, yüzündeki gülümsemeyi görmüyor. Kendini sandalyeye attı."

\footnotetext{
${ }^{16}$ Öğrencilerin metinlerindeki yazım hatalarına müdahale edilmemiştir.
} 
SB 15: "Naciye odadan çıktı."

\section{SB 16: "Memurlar dizilmişler, Naciye kırıta kırıta önlerinden geçti."}

Aşağıda sunulan işitsel düzgünün dökümünde ortam seslerinden sadece önemli olan ses efektleri döküme dâhil edilmiştir:

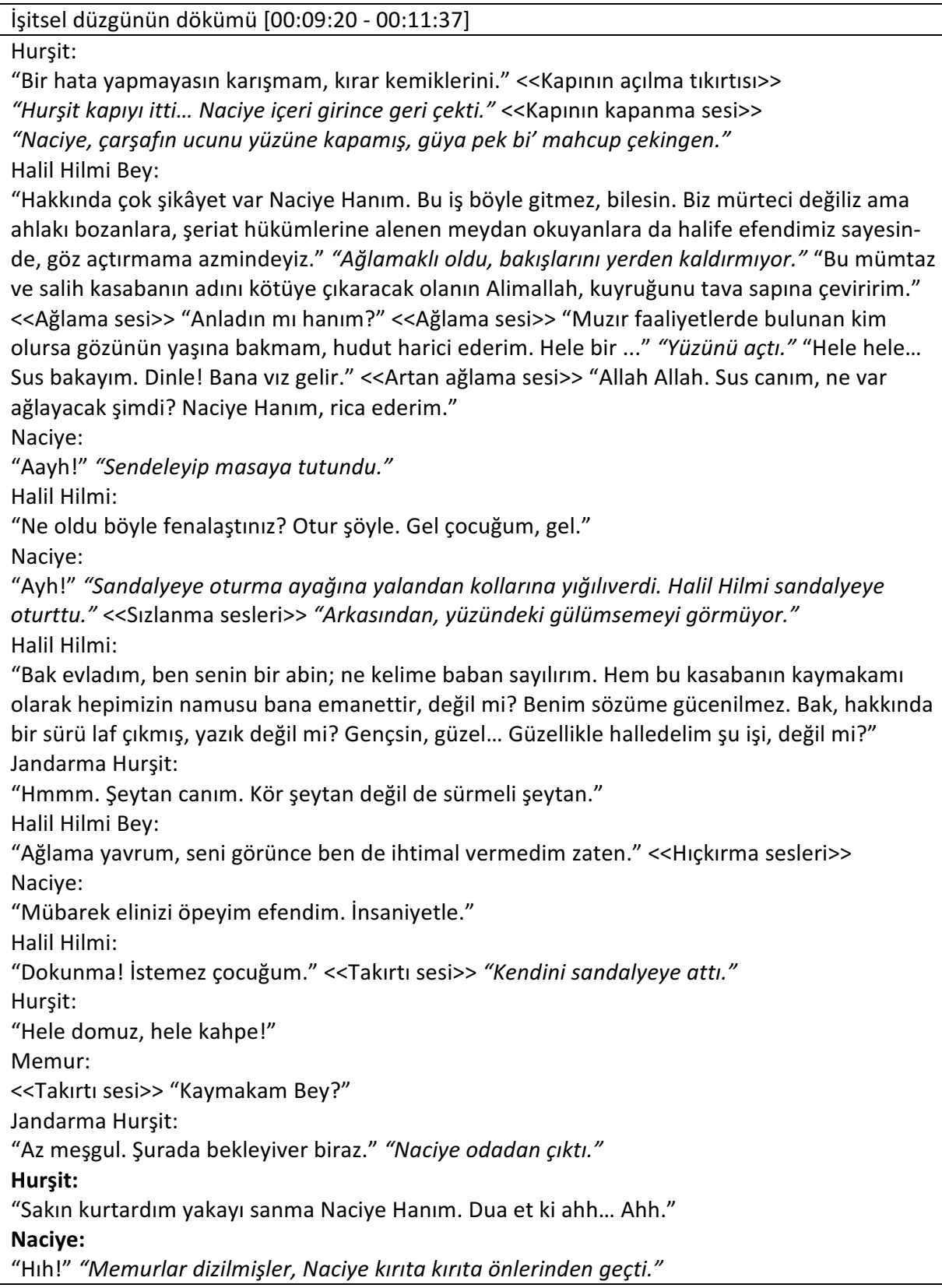


Halil Hilmi [Araştırmacının notu: Odasına giren Hurşit'e]:

"Böyle işte, muma döndü. Tanırım böylelerini, yumuşarsan yandın..."

Naciye kaymakamın odasına geldiğinde başı eğik, bakışları yerdedir. Kırmızı çarşaftan sadece gözleri ve alnının bir kısmı görünmektedir. Halil Hilmi Bey önündeki evrakla ilgilenir gibi yaparak sakin bir ses tonuyla konuşur. Ancak "azmindeyiz" sözcüğünde Naciye'nin yüzüne bakar. Naciye'nin yüzü ağlamaklıdır. Halil Hilmi konuşmasının temposunu arttır ve sesi tehditkâr bir ton alır. Ancak Naciye'nin ara ara hafif ağlama hıçkırıkları duyulur. Halil Hilmi sert konuşmaya gayret gösterse de Naciye'nin ağlıyor gibi yapıp kendine acındırması meyvelerini verir. Halil Hilmi Naciye’nin üzüldüğünü düşünerek sert tavrını sürdüremeyip yumuşar, hatta alttan alıp onu ahlaklı davranması için ikna etmeye çalışır. Hurşit bu görüşme sırasında kapıyı dinlemiştir. Kendisi, Naciye hakkında kendi kendine söylenirken kapıya kulağını dayamış biçimde gösterilmektedir. İkincisinde kapıyı dinlerken bir memura yakalanır. Naciye kapıdan çıktığında yüzünde üzgün bir ifade yoktur.

Bu sekansla ilgili öğrenci anlatımlarına bakıldığında, kapı dinlerken Hurşit'in söylenmelerini, metnine ${ }_{(1)}$ tek bir öğrencinin yansıtmış olduğu ortaya çıkmıştır. Öğrenci ${ }_{(10)}$ bu sahneyi aşağıda verilen şekilde ifade etmiştir:

... jandarma içeri giriyor. Böylelikle kadını gönderiyor. İçeri giren jandarma kadının bir şeytan olduğunu ahlaksızlık yapıp şikâyet edilecek gibi olursa ağladığını ayılıp bayıldığını söylüyor. [10- $\left.m_{(1)}\right]$.

[10- $m_{(1)}$ örneğinde sahne geçişlerinin anlaşılamadığından bilgilerin yanlış birleştirilmiş olduğu görülmektedir. Diğer öğrencilerin de, Hurşit'in söylenmelerini bir yere oturtamadıklarından bu sahneyi metinlerine $(1)$ yansıtmadıkları düşünülmektedir. Oysa Jandarma Hurşit Naciye'yi Halil Hilmi'nin odasına göndermek için koridorda bekliyor, SB örnek 9'da belirtildiği gibi kapıyı itiyor, Naciye kapıdan girdikten sonra da kapıyı çekiyor. Yani dışarda kalıyor. Kaymakamın yanında olsaydı kapıyı iterek kapatması gerekirdi.

İkinci izlemeden sonra kapı dinleme sahnesine metinlerinde ${ }_{(2)}$ yedi öğrenci yer vermiştir. Sesli betimlemede amaç bir defa izlemede işitsel filmin anlaşılmasının sağlanmasıdır. ${ }^{17}$ Bu sahnede betimleme yazarı tercihini (SB 8 ile) Naciye'yi betimlemekten yana kullanmıştır. Zaman kısıtından dolayı Hurşit'in kapıyı dinlediği betimlenememiştir. Yapılamayan bir betimleme görsel içerikten yoksun kalmak demektir. Bu eksik bilgi ise filmin alımlanmasını olumsuz yönde etkilemektedir. Betimlemede bazı kilit noktalara değinilmediğinde zihinde canlanan temsil filmdekinden farklı olabilir ya da yapılan yanlış yorumlar belirsizliğe neden olabilir.

Bu bölümde, aşağıda dört görseli (ekran görüntüleri 5-8) sunulan Naciye'nin ayrılışı sahnesi tartışılmıştır. Bu sahnede Naciye Hurşit'in sözlerini umursamadığını tepki-

\footnotetext{
${ }^{17}$ Bundan film izlerken hiçbir "şeyi" kaçırmayacağız sonucu çıkarılmamalıdır. Birçok kez, bir filmi ikinci kez izlediğimizde daha önce kaçırdığımız şeyleri fark ettiğimiz, yeni bağlamlar kurduğumuz olmuştur. Sonuç olarak ön bilgimiz alımlamayı yönlendirmektedir.
} 
siyle gösterir ve yürüyüp gider. Bu ayrılış sahnesiyle ilgili sesli betimlemenin (SB örnek 15 ve 16) öğrenci anlatımlarına nasıl yansıdığı gösterilmiştir:

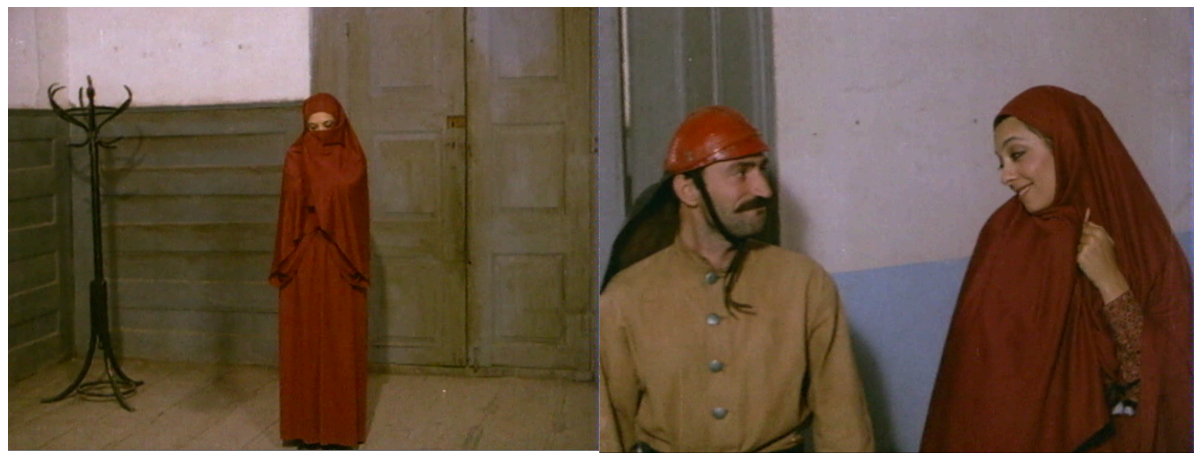

Ekran görüntüsü: 5 (SB 8)

Ekran görüntüsü: 6

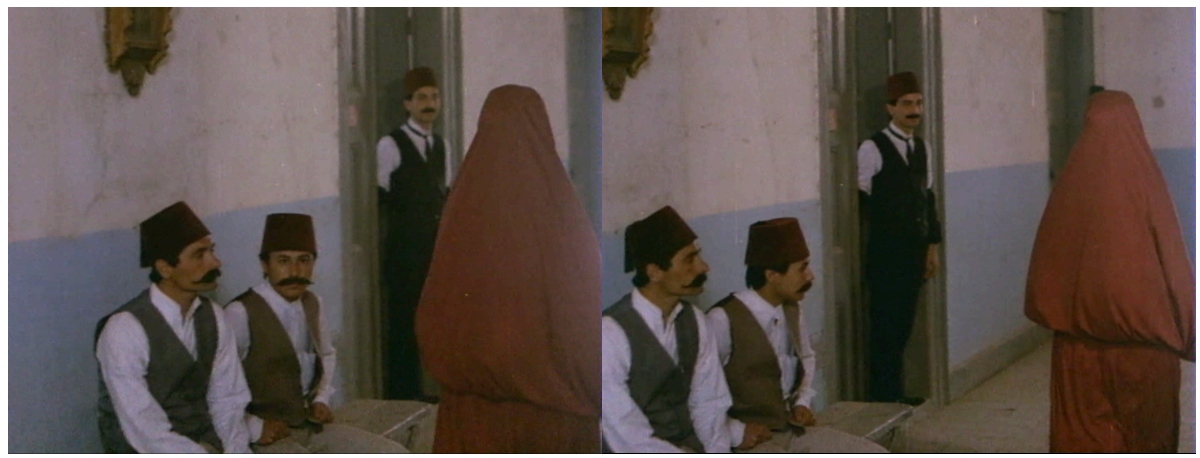

Ekran görüntüsü: 7 ve 8 (SB 16)

Öğrenci anlatımlarından örnekler

\begin{tabular}{|c|c|}
\hline $\begin{array}{l}\text { Betimlemeli sürüme ilişkin anlatımlar } \\
{\left[\mathrm{m}_{(1)}\right]}\end{array}$ & Kaynak sürüme ilişkin anlatımlar $\left[\mathrm{m}_{(2)}\right]$ \\
\hline 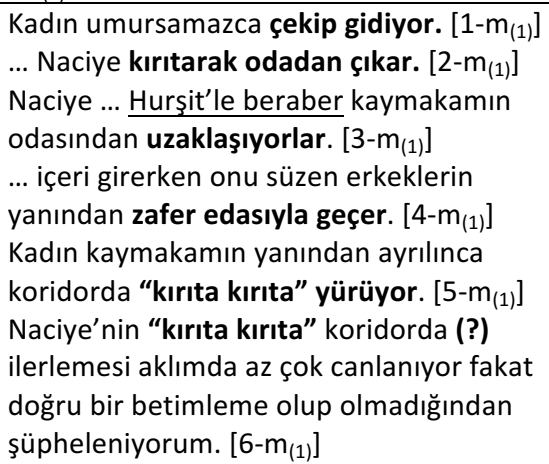 & 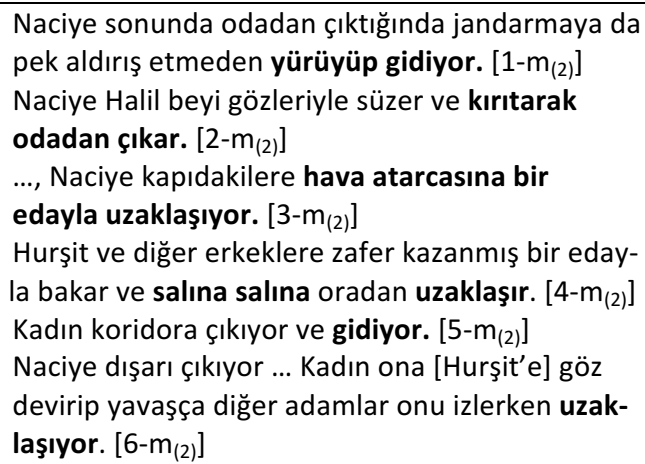 \\
\hline
\end{tabular}


SB örnek 16'da geçen “kırıta kırıta” kavramı üç öğrencinin görüntüyü izlemeden kaleme aldıkları metinlerde ${ }_{(1)}$ iz bırakmıştır. Bir öğrenci sonra da aynı ifadeyi (kırıtarak odadan çıkar) kullanmayı tercih etmiştir. Ancak, bu işten sıyrılmak için o kadar "çaba" sarf edip, ikna olmuş gibi görünüp hemen peşinden kaymakamın odasından kırıtarak çıkmak, hem de bol bir çarşafla, öykünün mantığı ve görseliyle pek bağdaşmamaktadır. SB örnek $16^{\prime} \mathrm{da}$, yürüyüş biçimini dillendirilirken filmin başından beri Naciye figürüyle ilgili konuşmalardaki basmakalıp yargıları pekiştiren cinsiyetçi bir betimleme ortaya çıkmıştır. Diğer iki öğrenci bu kavramı tırnak imi içinde yazarak, "kırıta kırıta" kavramıyla pek de hemfikir olmadıklarını metinlerine $(1)$ yansıtmışlardır. Bu nedenle de sonraki metinlerinde $_{(2)}$ bilinçli olarak "gidiyor/uzaklaşıyor" fiillerine yer vermişlerdir.

"Memurlar dizilmişler, Naciye kırıta kırıta önlerinden geçti." şeklindeki betimlemenin, kör ve görme engelli izleyicilerin Naciye figürü algısının biçimlenmesinde etkili olduğu düşünülmektedir. Bu bağlamda filmdeki dişil figüre ilişkin basmakalıp yargıların sesli betimlemeye eklemlendiği ve pekiştirildiği söylenebilir. Muhtemelen sorunlarını cilve yaparak çözmesi ve bağ evinde erkeklere oryantal dansı yapması nedeniyle bu figüre "kırıta kırıta" yürümek yakıştırılmıştır. Oysa bağ evindeki sahne daha sonra gösterilmektedir. Kılavuzda talep edilenin aksine, sesli betimleme her zaman yorumsuz ve yansız karşımıza çıkmamaktadır.

\section{Sonuç Yerine}

Bu çalışmada, gören öğrencilerin sesli betimlemeli bir filmi görüntüsüz izlediklerinde filmi nasıl alımladıkları, bunları nasıl kendi metinlerine yansıttıkları ve kaynak sürümü izledikten sonra kaleme aldıkları metinde ne gibi değişikliklere gittikleri gösterilmeye çalışılmıştır. Bu değişikliklerin kimisi ses tekniğiyle ilgilidir. Jenerikteki marş müziği sesi betimlemeyi adeta bastırmaktadır. Sesli betimlemeli filmin ses niteliğinden dolayı filmin giriş çekiminin alımlanmasında kimi öğrenciler sıkıntı yaşamışlardır. Bu gibi teknik durumlarla sesli betimlemeli filmlerin erek izleyicileri de karşılaşmaktadır. Sesli betimlemenin iyi ifade edilmesi yeterli değildir, ses tekniği de önemlidir.

Öğrencilerin yarısı giriş sahnesindeki çocuğu, zihninde erkek çocuğu olarak canlandırmıştır. Hatta bir öğrenci filmi görüntülü izledikten sonra da bir kız çocuğunun söz konusu olduğunun farkına varmamıştır. Buradaki çocuğun eril olarak düşünülmesi adamın anlattığı savaş konusuyla da ilişkilendirilebilir. Konuşmada tarih ve savaşla ilgili kavramlar geçmektedir. Savaş ve askerlik, erkeklerin hâkim olduğu bir alandır. Ayrıca çocuğun cinsiyetinin eril olarak algılanması örtük cinsiyet kavramıyla aydınlatılmaya çalışılmıştır.

Farklı açılardan ele alınmaya çalışılan bu sahne 98 dakikalık bir filmde sadece bir dakika kırk saniyelik bir zaman dilimini kapsamaktadır. Filmin devamında ne orta yaştaki adam ne de küçük kız, figür olarak bir daha gösterilmez, filmin öyküsüyle de başka bağları bulunmamaktadır. Dolayısıyla bu durum filmin öyküsünün anlaşılmasını olumsuz olarak etkilememektedir. Öyleyse çocuğun kız ya da erkek olmasının ne önemi var ki, diye düşünülebilir. Filmin giriş kısmında baba oğul ya da anne kız gösterilmemiş, 
bilakis iki cinsiyet birlikte temsil edilmiştir. Toplumsal cinsiyet ${ }^{18}$ eşitliği bakımından kızının eğitimiyle ilgilenen bir babanın ve öğrenen bir kız çocuğunun (veya dedeyle ve kız torunun) temsil edilmesi önemlidir. Değirmen (Yılmaz, 1986) filmindeki diğer dişil figürler geleneksel cinsiyet kalıplarını pekiştirip üretmektedir. Daha eşitlikçi bir toplumsal cinsiyet için dişil cinsiyetin bilgiyle iç içe temsil edilmesi önemlidir, ancak bu eşitlikçi tutumun kör ve görme engelli izleyicilere de aktarılması için sahnedeki dişil cinsiyetin doğru anlaşılması sağlanmalıdır.

Öğrenci grubunun yarısının çocuk betimlemesiyle eril cinsiyeti çağrıştırdığı düşünülürse kör ve görme engelliler arasında da benzer bir oran çıkması olası görünmektedir, daha kesin verilere kavuşmak için kör ve görme engellilerle bu ya da benzer konularda alımlama çalışması yapılması gerekmektedir.

Dillerarası çeviride açımlama stratejisine, kaynak okur kitlesi ile erek okur kitlesi arasındaki olası bilgi eksikliğinin giderilerek çeviri metninin anlaşılması için başvurulmaktadır. Bu çalışma çerçevesinde gören kaynak izleyicilerin sahip olduğu dünya bilgisiyle görmeyen erek izleyicilerinki arasında bir karşılaştırma söz konusu değildir. Açımlama tekniği kullanılarak betimlenen stetoskopsuz doktor sahnesi düşünüldüğünde, sesli betimlemede stetoskop terimine niçin yer verildiği anlaşılmamaktadır. Gören kaynak izleyici, bu sahnede gösterilen muayenenin aslında stetoskop kullanılmaksızın gerçekleştirildiğini nasıl kendisi keşfetmek durumundaysa, kör ve görme engelli erek izleyiciye de bu keşfetme fırsatı verilmelidir. Sesli betimlemenin amacı, gerçekleştirilmiş bir çıkarımın sonucunu görmeyen izleyiciye hazır sunmak olmamalıdır.

Naciye'nin başı eğik bekleme sahnesi (ekran görüntüsü 5) filmin sonuna doğru tekrarlanır. Tekrarlanan sahne için de aynı sesli betimleme (SB 10) kullanılmıştır: "Naciye, çarşafın ucunu yüzüne kapamış, güya pek bi' mahcup çekingen." Tekrarda aynı betimlemeye yer verilmesi filmin bağdaşıklığının betimlemeye aktarılması açısından çok yerinde bir karardır. Ancak, gören izleyici, Naciye'nin Halil Hilmi Bey'in makam odasına girdiği sahnede, Naciye'nin adının çıktığını konuşmalardan öğrenmiş olmakla birlikte, mahcup tavırlarının aslında "paçayı kurtarmak" için oynadığı bir rolden ibaret olduğunu henüz bilmemektedir. Betimlemede "güya" ifadesiyle öykünün devamına ilişkin ipuçları verilmiştir. Naciye odadan çıktığında da Hurşit'e göz devirip erkeklerin bakışlarına aldırmadan uzaklaşıyor. Sesli betimlemede (SB 16: "Memurlar dizilmişler, Naciye kırıta kırıta önlerinden geçti."), basmakalıp yargılar ön plana çıkarılarak, deyim yerindeyse, "fingirdek" bir figür imgesinin altı çizilmiştir. ${ }^{19}$ Bu tür örnekler sesli betimlemenin - daha doğrusu sesli betimlemeli filmlerin - disiplinlerarası olarak çalışılması

\footnotetext{
${ }^{18}$ Toplumsal cinsiyet, toplumun kadın ve erkekten beklediği kalıplaşmış rolleri ifade etmektedir. Erkek egemen bir toplumda, bu roller kadını özel alana, erkeği ise kamusal alana konumlandıracak şekilde biçimlenmiştir. Kadın ve erkekle ilgili toplumsal cinsiyet eşitsizlikleri çeşitli iletişim araçlarında sunularak yeniden üretilirler. Böylece toplumsal kültürel yapının sürekliliği sağlanmaktadır. Toplumsal cinsiyetle ilgili ayrıntılı bilgi için bkz. Butler (2014), Gümüşoğlu (2016) ve Fine (2011).

${ }^{19}$ Sesli betimlemenin zorlukları dikkate alındığında yorumsuz ve yansız bir betimleme yapmak neredeyse mümkün değildir, bu bağlamda Holland (2009, s. 177) yargılama yapmadan betimlemenin önemini vurgulamaktadır.
} 
gerektiğini göstermektedir, örneğin toplumsal cinsiyet araştırmalarına, film araştırmaları vs.

Görsel düzgüdeki her ögeyi betimlemek, filmin olay izleğinden koparabileceği gibi, bazı kilit sahnelerin betimlenememesi de filmin alımlanmasını olumsuz olarak etkilemektedir. Merkezî öneme sahip olan görsel ögeler betimlenemediğinde bazı sahneler yanlış anlamlandırılabilmekte ya da hiç anlaşılamamaktadır. Bu kimi ses efektleri için de geçerlidir. Gören izleyicinin, görsel düzgüyle ilişkilendirerek izlediğinde belki de önemli bulmadığından dolayı anımsamayacağı bir ses efektine, öğrenciler anlam yüklemeye çalışmışlardır. Örneğin, ayakkabı tamircisinden gelen çivi çakma sesleri [00:11:54-00:12:10], kaymakamın atla ilçede gezdiği biçiminde yorumlanmış ya da anlamlandırılmıştır. Öğrenciler, kör ve görme engellilerin işitme duyarlılığına sahip olmadıklarından sesli betimlemeli filmdeki bazı bilgileri takip edememişlerdir, örneğin bazı konuşmaların aynı kişiye ait olduğunu çıkaramamışlardır. Oysa kör ve görme engelliler kişileri zaten sesiyle tanımaktadırlar. Bu nedenle, kör ve görme engelli izleyicilerle alımlama çalışmalarının yapılmasının önemi vurgulanmaktadır.

Öğrencilerin bu deneysel çalışmadan kazanımları, betimlemede nelere dikkat etmeleri gerektiği konusunda bilgi ve becerilerini geliştirmeleri olmuştur. Bunlar kısaca; sahne geçişleri, mekânın belirtilmesi, konuşan kişilerin kısaca belirtilmesi, anlaşılmayan ortam seslerinin açıklanması, betimlemenin zamanı, yansız ifade, ipucu vermeme vb. olarak sıralanabilir. Öğrenciler, bu yöntemi faydalı bulduklarını belirtmişlerdir. Hatta, iki öğrenci sesli betimleme kullanıcılarının ihtiyaçlarını daha iyi saptayabilmek ve bu konuda duyarlılık geliştirmek amacıyla bir süre, betimlenecek kaynak filmin önce görüntüsüz olarak izlenmesini önermiştir. Bir eğitim aracı olarak böyle bir aşama uygulanabilir. Ancak, bu yöntemin piyasada zaman baskısından dolayı pek rağbet görmesi olası değildir. Sesli betimleme derslerine kör ve görme engelli öğrencilerin katılımının faydalı olacağı düşünülmektedir. Zira Benecke’nin verdiği bilgilere göre, Almanya'da başta, üç kişi birlikte çalışarak bir filmi betimlemişlerdir; bir kör ve iki gören betimlemeci (2014, s. 14). Üç betimleme uzmanının birlikte çalışması, hem kör ve görme engelli izleyiciler için önemli olan bilgilerin atlanmamasını sağlamıştır hem de yansız bir betimlemenin üretimine katkıda bulunmuştur. Bir gören betimlemecinin "göremediğini" diğerinin "görmesinin" de betimleme niteliğini yükselttiği söylenebilir. Benecke, maliyeti düşürmek amacıyla 2013 yılında bu uygulamanın terkedildiğini belirtmiştir (a.g.y.). Sesli betimleme eğitiminde, gören ve görmeyen öğrencilerin birlikte çalışmalarının sağlanması her iki grup için de verimli olacaktır.

Sesli betimleme kılavuzları, betimlemenin nasıl yapılması gerektiğini yazarak kural koyucu ve normatif nitelik taşımaktadır. Örneğin, bu kurallardan biri şimdiki zamana yer verilmesi biçimindedir. Bu kural Türkçeye uymadığından, Türkçe betimlemelerde hem şimdiki zaman hem de geçmiş zaman kullanılmaktadır. Bu incelemede de kılavuzlar temel alınmıştır. Ancak, bu kılavuzlara harfiyen uymak yerine belki de bazen kimi kurallara istisna getirmeyi düşünmek gerekmektedir. Bu bağlamda elbette betimleme kullanıcılarının görüşleri ve beklentileri belirleyicidir. Bu beklentileri tespit etmek için betimleme kullanıcılarına bir film kesitiyle ilgili farklı betimlemeler sunularak, onların 


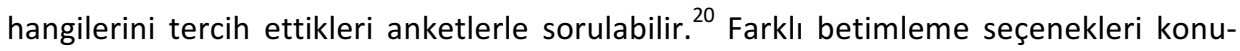
sunda diğer dillerde hazırlanmış betimlemeler de esin kaynağı olabilir.

\section{Kaynakça}

ACB (2018). The Audio Description Project. http://www.acb.org/adp/guidelines.html (06.02.2018)

Aral, U. (Yönetmen/Yapımcı) ve Atay, Ö. (Yapımcı) (2005). Çarpışma [Kısa Metrajılı Film]. Türkiye. https://www.imdb.com/title/tt0759905/ (Son erişim tarihi: 01.04.2019)

Ayverdi, ì. (2011). Misalli Büyük Türkçe Sözlük. 4. Baskı, İstanbul: Kubbealtı Lugatı Yayınları.

Baş, N. (2016). Görsel-Işitsel Çeviri, Dublaj ve Sesli Betimleme. Ankara: Grafiker Yayınları.

Benecke, B. (2004). Audio-Description. Meta: Translators' Journal, 49(1), 78-80. http://id.erudit.org/iderudit/009022ar

Benecke, B. (2014). Audiodeskription als partielle Translation. Modelle und Methode. Berlin: Lit.

Benecke, B. (2014). Der Ton macht die Audiodeskription. Sprache barrierefrei gestalten. Perspektiven aus der Angewandten Linguistik (s. 109-125). Berlin: Frank \& Timme,.

Braun, F. (2000a). Gender in the Turkish language system. Turkic Languages 4, 3-21.

Braun, F. (2000b). Geschlecht im Türkischen. Untersuchungen zum sprachlichen Umgang mit einer sozialen Kategorie. Wiesbaden: Harrassowitz.

Butler, J. (2014). Cinsiyet Belası. (Çev. B. Ertür), 4. Baskı, İstanbul: Metis Yayınları.

Chmiel, A. ve Mazur, I. (2012). AD reception research: Some methodological considerations. (Ed: E. Perego) Emerging Topics in Translation: Audio description (pp. 57-80). Trieste: EUT. https://www.openstarts.units.it/bitstream/10077/6361/1/Chmiel_Mazur_EmergingTopi cs.pdf

Fine, C. (2011). Toplumsal Cinsiyet Yanılsaması. Zihnimiz, Toplum ve Nörocinsiyetçilik Nasıl Fark Yaratıyor? (Çev. K. Tanrıyar), İstanbul: Sel Yayıncılık.

Guidelines on the Provision of Television Access Services (t.y.). https://www.ofcom.org.uk/_data/assets/pdf_file/0023/19391/guidelines.pdf (son erişim tarihi 20 Şubat 2019)

Gümüşoğlu, F. (2016). Ders Kitaplarında Toplumsal Cinsiyet, 1928'den Günümüze. 4. Baskı, İstanbul: Tarihçi Kitabevi.

Günay, Z. (Yönetmen) (2010-2013). Öyle Bir Geçer Zaman Ki [Televizyon Dizisi]. Türkiye: D Productions. http://www.imdb.com/title/tt1784141/

Holland, A. (2009). Audio Description in the Theater and the Visual Arts: Images into Words. J. Diaz Cintas ve G. Anderman (Eds.). Audiovisual Translation: Language Transfer on Screen (pp. 170-185). Basingstoke: Palgrave Macmillan.

\footnotetext{
${ }^{20}$ Chmiel ve Mazur (2012) Polonya'daki sesli betimleme standartlarını ve sesli betimlemeyi iyileştirmek için uyguladıkları anket aşamalarını tartışmaktadır.
} 
ITC (2000). ITC Guidelines on Standards for Audio Description.

http://audiodescription.co.uk/uploads/general/itcguide_sds_audio_desc_word3.pdf (son erişim tarihi 15 Temmuz 2018)

Kerimoğlu, C. ve Doğan, G. (2015). Türkçede Cinsiyet Görünümleri ve Çağrışımsal Zihniyet. Türklük Bilimi Araştırmaları, 38, 143-178. http://dergipark.gov.tr/download/article$\underline{\text { file/157239 }}$

Nöth, W. (2000). Der Zusammenhang von Text und Bild, (Ed: K. Brinker, G. Antos, W. Heinemann, S. F. Sager), Text- und Gesprächslinguistik. Ein internationales Handbuch zeitgenössischer Forschung (s. 489-496). Berlin/New York: de Gruyter.

Ofcom (2017) https://www.ofcom.org.uk/_data/assets/pdf_file/0020/97040/Access-servicecode-Jan-2017.pdf (son erişim tarihi 12.07.2018)

Okyayuz, A. Ş. (2017). Sesli Betimlemenin Çeviribilim Sınıflarında Tanıtımı için Bir Eğitim Bileşeni Önerisi. Turkish Studies, International Periodical for the Languages, Literature and History of Turkish or Turkic, 12/22, 559-586.

Peçenek, D. ve Gökmen, S. (2018). Türkçede Çağrışımsal Cinsiyet Görünümleri. 32. Ulusal Dilbilim Kurultayı, 3-4 Mayıs 2018, İzmir, Bildiri Özetleri, 34-35.

Sesli Betimleme Derneği - Betimleme Kumbarası (t.y.) http://www.sebeder.org/betimlemekumbarasi.php (son erişim tarihi 06.07.2018)

Sesli Betimleme Derneği - Hakkımızda (t.y.) http://www.sebeder.org/hakkimizda.php (son erişim tarihi 06.07.2018)

Snyder, J. (2014). The Visual made verbal, A Comprehensive Training Manual and Guide to the History and Applications of Audio Description. Arlington: ACB.

Tan, B. (13.02.2013). Bir Devrin Sonu: Değirmen. https://filmhafizasi.com/bir-devrin-sonudegirmen/ (Son erişim tarihi 09.08.2018)

Tanış Polat, N. (2009). Çeviribilim ve Dilbilim Bağlamında Türkiye'de Sesli Betimlemenin Yeri ve Önemi. Dilbilim Araştırmaları, 2009(1), 1-10.

http://turkoloji.cu.edu.tr/DILBILIM/np_betimleme/np_betimleme.htm

Yılmaz, A. (Yönetmen) (1986). Değirmen [Sinema Filmi]. DVD. Türkiye: Odak Film. 